\title{
Patterns and implications of male migration for HIV prevention strategies in Andhra Pradesh
}

Ravi K. Verma

Niranjan Saggurti

Population Council

Madhumita Das

Saumya RamaRao

Population Council

Anrudh K. Jain

Population Council

Follow this and additional works at: https://knowledgecommons.popcouncil.org/departments_sbsr-hiv

Part of the Demography, Population, and Ecology Commons, Family, Life Course, and Society Commons, International Public Health Commons, Medicine and Health Commons, and the Migration Studies Commons How does access to this work benefit you? Let us know!

\section{Recommended Citation}

Verma, Ravi K., Niranjan Saggurti, Madhumita Das, Saumya RamaRao, and Anrudh K. Jain. 2007. "Patterns and implications of male migration for HIV prevention strategies in Andhra Pradesh," Technical brief. New Delhi: Population Council. 


\title{
Patterns and Implications of Male Migration for HIV Prevention Strategies in Andhra Pradesh
}

\author{
Ravi K. Verma, Niranjan Saggurti, Madhumita Das, Saumya RamaRao, and Anrudh Jain
}

$\mathrm{H}$

IV is widespread in Andhra Pradesh.

Among Indian states Andhra Pradesh has

recorded the highest HIV prevalence

among pregnant women receiving antenatal care

(ANC) and patients receiving treatment for sexually transmitted diseases (STDs), according to data from India's surveillance system. High HIV prevalence among women indicates that the infection, rather than being restricted to groups at high risk, is present in the general population of Andhra Pradesh. Prevalence among STD patients has increased from 16 percent in 2004 to 23 percent in 2005 (NACO 2006). And 19 of the state's 23 districts have recorded HIV prevalence of more than 1 percent among pregnant women attending antenatal clinics in 2005.

Districts with high HIV prevalence are also the destinations for large numbers of male migrants. Andhra Pradesh ranks third nationally in the proportion of total migrants. Maharashtra and Uttar Pradesh rank first and second respectively (Registrar General of India 2001). There is a growing consensus among policymakers and program managers in Andhra Pradesh that migration could be a major contributor to the spread of HIV in the state (APSACS 2006). However, empirical evidence to support this conjecture is limited.

Furthermore, evidence is required to maximize the impact of programmatic inputs intended to contain the spread of the epidemic.

The India AIDS Initiative, Avahan, recognizing the need for evidence to inform HIV prevention programs, gave a grant to the Population Council

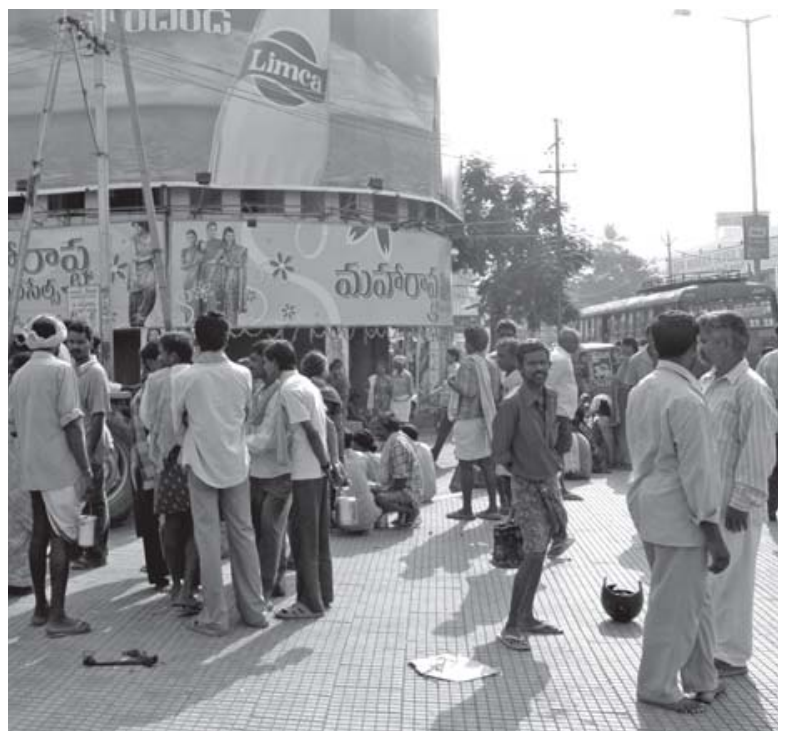

Large numbers of semi-skilled and unskilled men, most of whom are migrants, gather at "labor addas" (pick-up points) looking for employment for the day.

to study the patterns and motivations related to migration/mobility of male laborers and sex workers and to examine the links with HIV risk. As part of this study, the Council conducted a systematic analysis of the 2001 census data on migration and other available data on HIV prevalence. The purpose was to document patterns of male migration and determine whether there were overlapping trends between migration and HIV prevalence (APSACS 2002) that would indicate a relationship between migration and HIV infection. In particular, the analysis sought to answer the following questions: 
- What is the pattern of male in- and out-migration at the state level? What is the volume of male in-migration and the change over time?

- What is the pattern of male in- and out-migration at the district level? Which districts attract large numbers of migrant men and from where?

- What are the dominant streams of male inmigration? Is it rural to rural, rural to urban, or urban to urban?

- Is there a relationship between HIV prevalence and migration patterns at the district level?

\section{Data and methods}

We used two sources of data for the analysis presented here. The 2001 census of India, like previous censuses, collected information on migration for all individuals by place of birth and last residence. Data on last residence, along with details such as duration of stay at the current residence and reason for migration, provide useful insights for studying migration dynamics. Data on HIV prevalence among ANC and STD clinic attendees were obtained from the published reports of the Andhra Pradesh State AIDS Control Society (APSACS 2002).

We use a range of methods - univariate statistics for measuring levels, and bivariate and rank correlation to examine relationships. A crosstabulation of the place of last residence by duration of residence at the place of enumeration examines patterns of migration and changes over time. Data on HIV have been overlayed with data on migration to examine the relationship between migration and HIV.

The percentages of men migrating within districts, across districts, and across states were calculated to define the patterns of movement. We present intradistrict, ${ }^{1}$ interdistrict, ${ }^{2}$ and interstate $^{3}$ migration streams by rural-urban residence to document migration patterns among men in Andhra Pradesh. We used a rank correlation coefficient method to examine the average relationship between volume of migration and HIV prevalence among ANC and STD clinic attendees. We ranked the districts according to the volume of both in- and out-migration.
We then calculated the average of the two ranks. We also ranked the districts according to HIV prevalence among ANC and STD clinic attendees. We then plotted the average ranks of districts according to migration on a scatter diagram against the ranks according to HIV prevalence among ANC clinic attendees to examine their relationship. Further, we plotted ranks of in-migration against ranks according to HIV prevalence among STD clinic attendees to assess their relationship.

\section{Male migration in Andhra Pradesh}

According to the 2001 census, Andhra Pradesh has experienced net male out-migration at the state level. During 1991-2001, 292,667 males moved out of the state while 183,890 males entered. The census figures also indicate that approximately half a million men were on the move. Males from Andhra Pradesh migrate to most other major states in India; their most popular destinations are Karnataka, Maharashtra, Tamil Nadu, and Orissa (see Figure 1). The first three states plus Rajasthan are also the most popular sending states.

A comparison of migrant males in the 1991 census who lived 0-9 years at their current residence with migrants in the 2001 census who lived 10-19 years at their current residence indicates that a substantial number of migrant males who arrived in Andhra Pradesh during 1981-91 (some 56 percent) had changed their place of residence by the year 2001. This suggests that migrant men within the state are highly mobile.

Among all males migrating to Andhra Pradesh from other states during 2000-01, most entered the districts of Rangareddi (14.9 percent), Karimnagar (9.9 percent), and Chittoor (7.8 percent), with the remainder going to one of the

\footnotetext{
${ }^{1}$ A person who moves from his place of usual residence or birth to another politically defined area (village/town) within the same district of enumeration is an intradistrict migrant.

${ }^{2}$ A person who crosses the boundary of the district of enumeration but remains within the state of enumeration is an interdistrict migrant.

${ }^{3}$ A person whose place of enumeration lies in a different state from his/her place of birth or last residence is an interstate migrant.
} 
FIGURE 1 Dominant trends in interstate migration from and to Andhra Pradesh, 2001

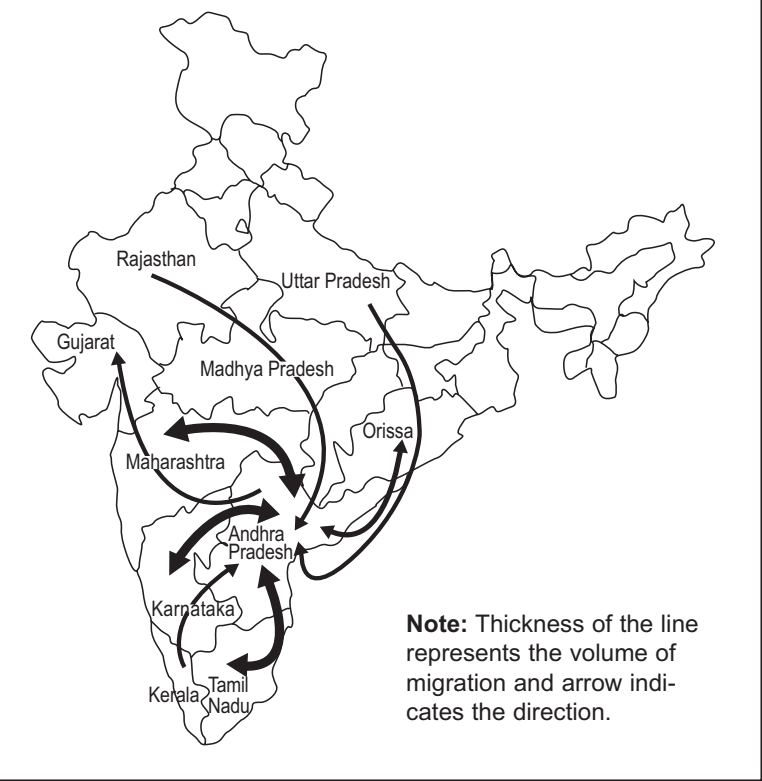

state's other 20 districts. The districts of other states that have contributed prominently to male migration to Andhra Pradesh are Mumbai in Maharashtra; Gajapati and Balangir in Orissa; Jalor and Sirohi in Rajasthan; Chennai, Salem, and Madurai in Tamil Nadu; and Bidar, Gulbarga, Bellary, and Bangalore in Karnataka. Two-thirds of the men who entered Andhra Pradesh from other Indian states have migrated from one urban area to another.

\section{Male migration at the district level}

Interdistrict migration data show a predominance of male migration to a few coastal districts of Andhra Pradesh. Out of the 23 districts in the state, seven-namely, Krishna, East Godavari, Guntur, Nellore, West Godavari, Visakhapatnam, and Rangareddi-drew around half of all male migrants from other districts in the state.

Interdistrict male migration in Andhra Pradesh during the intercensal period 1991-2001 was concentrated in two pockets: one in the eastern coastal districts of Krishna, Visakhapatnam, and West Godavari; the other in the western districts of Rangareddi and Hyderabad (see Figure 2). A notable decline in the proportion of interdistrict
FIGURE 2 Dominant trends in interdistrict male migration to the major in-migrating districts of Andrha Pradesh

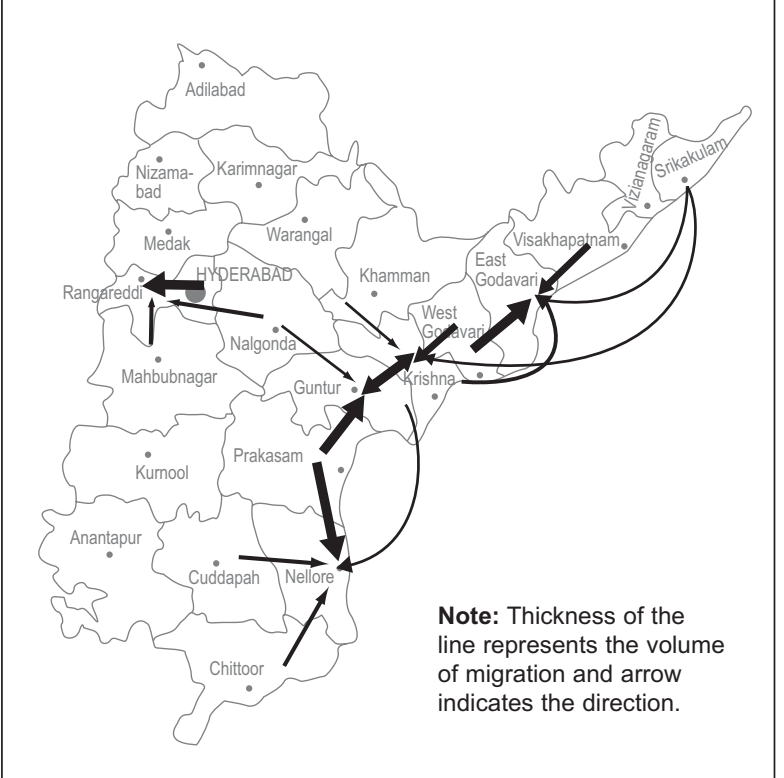

male in-migration occurred in Hyderabad and Visakhapatnam, while an increase in in-migration took place in Guntur and Nellore. Krishna, Hyderabad, Visakhapatnam, and Rangareddi account primarily for in-migration while West Godavari, Guntur, and Nellore account primarily for out-migration.

Intradistrict migration is concentrated mainly in the coastal districts, particularly in East Godavari. Districts in western Andhra Pradesh experienced very low levels of within-district migration.

\section{Male migration streams}

During the last two intercensal periods (1981-91 and 1991-2001) the number of males counted as migrants - that is, enumerated in places other than their place of birth or previous residenceincreased by 26 percent. In-migration to Andhra Pradesh rose slightly between the 1991 and 2001 censuses. ${ }^{4}$ A large majority of the migrants have

\footnotetext{
${ }^{4} \mathrm{~A}$ large number of migrant males in the 2001 census did not indicate the duration of their stay in the place of enumeration. It is therefore difficult to assess the actual increase in the volume of migrants between the two censuses.
} 
moved within the state, either from elsewhere in the same district or from other districts. During 2000-01, 62 percent of male migrants moved within the same district, 30 percent moved from other districts within the state, and 8 percent came from other Indian states (see Table 1).

New patterns of movement have emerged in the last few years. Short-distance male migrants or those who move within districts as a share of all migrants have declined from 63 percent during 1991-96 to 62 percent during 2000-01. The proportion of males coming to Andhra Pradesh from other Indian states in search of work/employment has increased from 6 percent to 8 percent within the same ten-year interval (Table 1). Although the percentage change is small, this is an emerging trend that deserves our attention.

Districts that have received large numbers of migrants from other states have not attracted local men from short distances. This observation suggests the likelihood of skilled male migration to these districts from outside the state.

Rural-to-rural migration is the dominant type of movement among males who move within districts, whereas the urban-to-urban and ruralto-urban ${ }^{5}$ migration are the dominant types of movement among those who move between states (see Figure 3). More than half of males from the high-volume migration districts of East Godavari, West Godavari, Krishna, Guntur, and Nellore move between rural areas. Urban-tourban migration within districts is the primary type of movement in Hyderabad (81 percent) and Rangareddi (28 percent). The primary reasons given for mobility are work/employment and education. About 70 percent of males who moved

\footnotetext{
${ }^{5}$ The 2001 census of India defined urban areas as follows: (a) All statutory places with a municipality, corporation, cantonment board, or notified town area committee, etc., (b) A place satisfying the following three criteria simultaneously:

(i) a minimum population of 5,000 ;

(ii) at least 75 percent of male working population engaged in nonagricultural pursuits; and

(iii) a population density of at least 400 per sq. km. (1,000 per sq. mile).
}

TABLE 1 Percent share in type of male in-migration by duration of residence at the place of enumeration, 2001

\begin{tabular}{|c|c|c|c|c|c|c|}
\hline \multirow[b]{2}{*}{$\begin{array}{l}\text { Type of male } \\
\text { in-migration }\end{array}$} & \multicolumn{6}{|c|}{ Duration of residence } \\
\hline & $\begin{array}{l}\text { Less } \\
\text { than } \\
1 \text { year }\end{array}$ & $\begin{array}{l}1-4 \\
\text { years }\end{array}$ & $\begin{array}{l}5-9 \\
\text { years }\end{array}$ & $\begin{array}{l}10+ \\
\text { years }\end{array}$ & $\begin{array}{l}\text { Duration } \\
\text { not } \\
\text { stated }\end{array}$ & Total \\
\hline Intradistrict & 61.8 & 63.1 & 63.4 & 63.2 & 82.2 & 69.4 \\
\hline Interdistrict & 30.2 & 30.0 & 30.4 & 30.2 & 15.2 & 25.2 \\
\hline Interstate & 7.8 & 6.8 & 6.0 & 6.2 & 2.4 & 5.1 \\
\hline $\begin{array}{l}\text { Total of male } \\
\text { in-migrants } \\
(000) \\
\left(\text { percent }{ }^{*}\right)\end{array}$ & $\begin{array}{c}301.6 \\
(100.0)\end{array}$ & $\begin{array}{c}1,480.8 \\
(100.0)\end{array}$ & $\begin{array}{c}998.7 \\
(100.0)\end{array}$ & $\begin{array}{c}2,485.4 \\
(100.0)\end{array}$ & $\begin{array}{c}2,572.8 \\
(100.0)\end{array}$ & $\begin{array}{r}7,839.3 \\
(100.0)\end{array}$ \\
\hline
\end{tabular}

* The column entries may not sum to totals due to a small percentage of international migration.

Source: Calculated from census.

to rural areas did so either for work in agriculture or because family members had moved.

Census data also provide a sociodemographic profile of migrants. On average, 30 percent of migrant males are between ages 20 and 29, and more than 50 percent are unmarried. The data also indicate a predominance of male migration in the working-age years of 30-59.

FIGURE 3 Migration streams in Andhra Pradesh, 2001

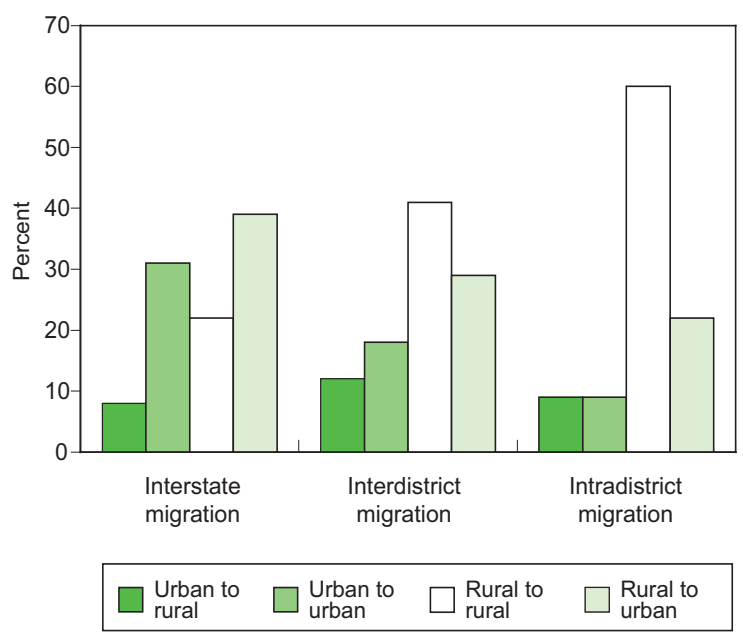

Source: Calculated from census. 


\section{Links between migration and HIV prevalence}

The male in-migration rate (the proportion of migrant males during 1991-2001 among all males) is high in the districts of Krishna, East Godavari, Guntur, Nellore, Hyderabad, and Rangareddi. These districts have also recorded a very high prevalence of HIV infection among persons attending ANC and STD clinics. Districts that record high rates of out-migration, such as Guntur, Prakasam, and Karimnagar, also have high levels of HIV prevalence among the general population. Table 2 indicates district-level HIV prevalence among ANC and STD clinic attendees for 2001 and 2005.

Figure 4 suggests that districts in Andhra Pradesh with high levels of migration-both in-

TABLE 2 HIV prevalence in Andhra Pradesh by district, 2001 and 2005

\begin{tabular}{|c|c|c|c|c|}
\hline \multirow[b]{2}{*}{ District } & \multicolumn{2}{|c|}{$\begin{array}{l}\text { STD clinic } \\
\text { attendees }\end{array}$} & \multicolumn{2}{|c|}{$\begin{array}{l}\text { ANC clinic } \\
\text { attendees }\end{array}$} \\
\hline & 2001 & 2005 & 2001 & 2005 \\
\hline Adilabad & 0.75 & 1.75 & & \\
\hline Anantapur & 1.25 & 1.75 & & \\
\hline Chittoor & 39.2 & 22.8 & 1 & 1.25 \\
\hline Cuddapah & & & 1.75 & 0.75 \\
\hline East Godavari & 30.4 & 14.8 & 3 & 2.75 \\
\hline Guntur & & & 2.25 & 3 \\
\hline Hyderabad & 31.6 & 32.4 & 1.5 & 2 \\
\hline Karimnagar & 3.75 & 20.4 & 1.5 & 2.25 \\
\hline Khammam & 12.8 & 31.2 & 0.25 & 3.5 \\
\hline Krishna & 33.2 & 26.4 & 2.25 & 2 \\
\hline Kurnool & 9.2 & 15.2 & 0.5 & 1.5 \\
\hline Mahbubnagar & & & 0.25 & 0.25 \\
\hline Medak & 3.2 & 4 & 1.25 & 2 \\
\hline Nalgonda & & & 1.75 & 2.75 \\
\hline Nellore & & & 1 & 1.5 \\
\hline Nizamabad & & & 1.25 & 0.75 \\
\hline Prakasam & 12.8 & 19.6 & 3.5 & 2.5 \\
\hline Rangareddi & & & 1 & 1.75 \\
\hline Srikakulam & & & 0.75 & 1.5 \\
\hline Visakhapatnam & 35.6 & 32 & 0.5 & 2.5 \\
\hline Vizianagaram & & & 1 & 1.25 \\
\hline Warangal & 40.4 & 23.7 & 6.75 & 2.5 \\
\hline West Godavari & & & 2.25 & 3.25 \\
\hline
\end{tabular}

Sources: APSACS (2002); NACO (2006). and out-migration - also rank high on HIV prevalence among pregnant women attending ANC clinics. Figure 5 suggests a similar relationship between high in-migration rates and HIV prevalence among patients at STD clinics.

\section{Discussion}

Census data for Andhra Pradesh suggest a preponderance of intrastate migration in most of the coastal districts and large migration flows to the districts of Hyderabad and Rangareddi from other Indian states. Male in-migrants from other states come from high-HIV-prevalence districts in Maharashtra, Tamil Nadu, and Karnataka. A large

FIGURE 4 Migration and HIV prevalence among ANC clinic attendees: District-wise ranks

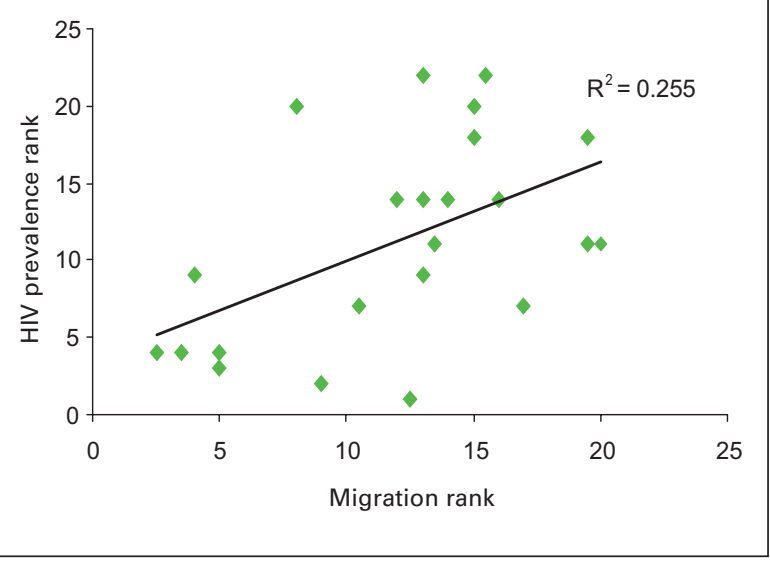

FIGURE 5 In-migration and HIV prevalence among STD clinic attendees: District-wise ranks

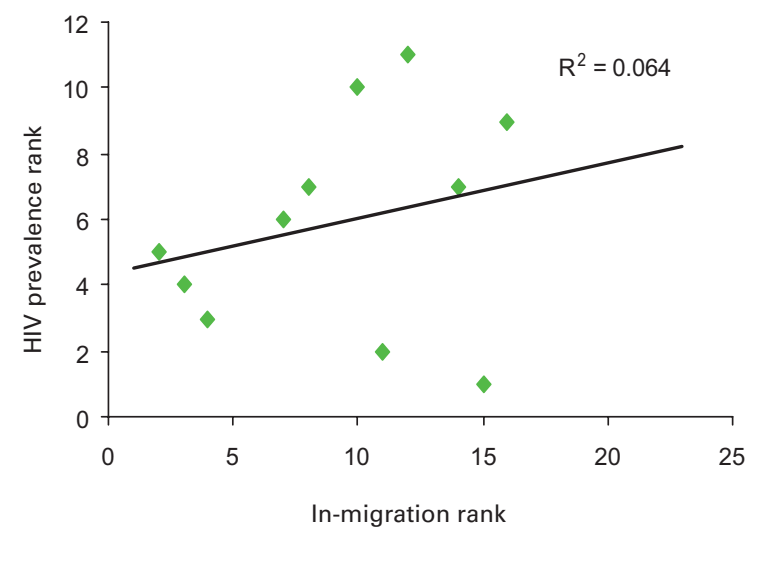


proportion of such migrants are either single or have left their spouses and families behind. These patterns suggest the possibility of a correlation between migration and HIV prevalence. However, we caution against such a conclusion since migration per se does not put a male migrant at risk of acquiring HIV. Indeed, clarification of the relationship between migration patterns and HIV preva-

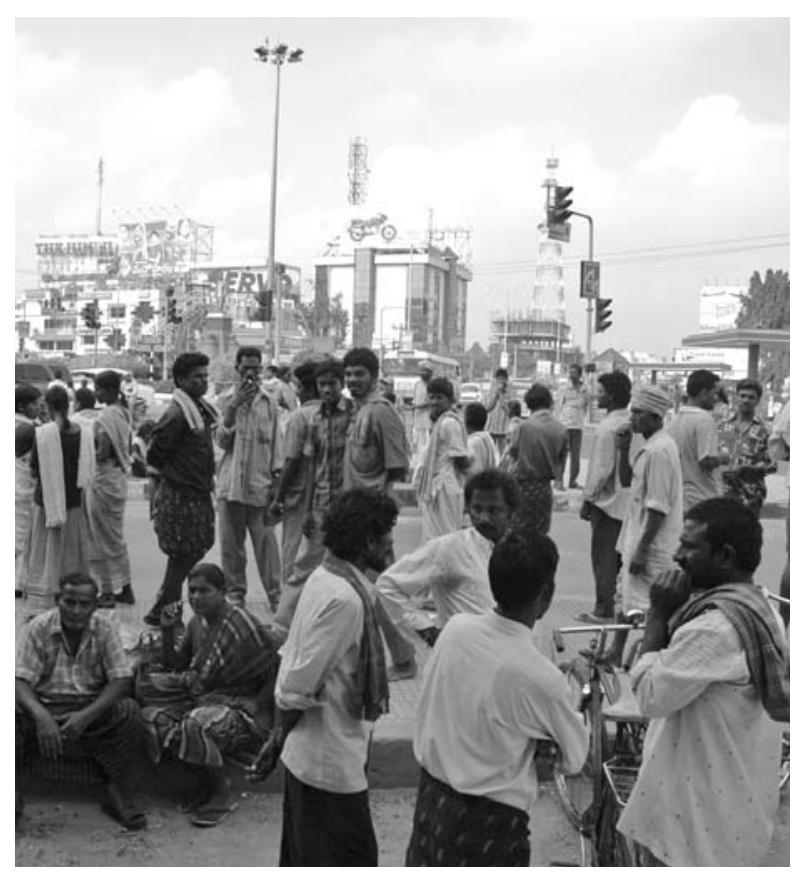

Officials in Andhra Pradesh believe that migration could be a major contributor to the spread of HIV within the state.

lence requires more in-depth analysis of individual-level factors. As mentioned earlier, seven of Andhra Pradesh's 23 districts drew around half of the total male in-migrants in the state. Districts with high levels of out-migration to other districts also have high rates of HIV prevalence among attendees at ANC and STD clinics. Thus, it is not only the destination districts of male migrants that are vulnerable to the HIV epidemic. The majority of districts that contributed to male migration to other districts of Andhra Pradesh are themselves locations for potential HIV inter- ventions. In other words, many male migrants originated from districts that have high rates of HIV prevalence.

Further, migrant males are self-selected individuals who are potential candidates for HIV prevention programs. For example, recent migrants retain links with their places of origin and are likely to be more mobile than the general population. It is also likely that they live in groups and are therefore more easily reached by prevention programs. The results of the present analysis suggest that the districts of East Godavari, Krishna, Guntur, Rangareddi, and Nellore, all of which drew large numbers of male migrants from elsewhere in the state, are sites with high potential for HIV prevention programs in Andhra Pradesh.

\section{Implications for further research}

Migration data from the 2001 census are indicative of broad patterns and trends over time. Some of the questions to be addressed in future research to inform program design and investment of resources include:

- What are the implications for male migrants of moving from areas with low/high HIV prevalence to areas with low/high HIV prevalence in terms of the spread of virus?

- What are the potential risks facing migrants in different destination areas?

- How do migrant populations' risk patterns influence the risk patterns of non-migrant populations in various destination areas?

- Should there be different types of programs for sites of migrant origin and destination?

- Who will be the primary and secondary beneficiaries of programs? For example, should interventions focus equally on migrants and non-migrants?

- What should be the content of the interventions-for example, education, outreach, condom promotion? 


\section{References}

APSACS (Andhra Pradesh State AIDS Control Society). 2006. HIV Prevention. <http://www. apsacs.org/english/hivprevention.htm>. Accessed 9 October 2006.

2002. Preliminary Report of HIV Sentinel Surveillance Survey for the Year 2002. <http://www.apsacs.org/english/reports6.htm>.

NACO (National AIDS Control Organisation). 2006. HIVIAIDS Epidemiological Surveillance \&
Estimation Report for the Year 2005. Ministry of Health and Family Welfare, Government of India. <http://www.nacoonline.org/fnlapil06rprt.pdf>.

Registrar General of India. 2001. Census of India: Andhra Pradesh. D series (Migration tables).

\section{Acknowledgment}

Financial support from Avahan, the India AIDS Initiative of the Bill \& Melinda Gates Foundation, is gratefully acknowledged. 
The Technical Brief series summarizes results from Population Council research. The Population Council conducts biomedical, social science, and public health research and develops reproductive health products. The Council works in three programmatic areas: HIV and AIDS; poverty, gender, and youth; and reproductive health.

For more information, contact:

Ravi K. Verma

Population Council

Zone 5A, India Habitat Centre,

New Delhi 110003

rverma@popcouncil.org

(c) 2007 The Population Council, Inc. 